\title{
Determinação sorológica da Arterite Viral Eqüina em eqüinos hígidos, com abortamento e com sintomas de alteração do sistema respiratório
}

\section{Serological determination of equine arteritis virus in horses with abortion and symptoms of respiratory alteration}

\author{
Wilson Roberto Fernandes, ${ }^{\star}$ Maria do Carmo Custódio de Souza**
}

\begin{abstract}
Resumo
Foi pesquisada a presença de anticorpos antivírus da arterite viral dos eqüinos em cavalos criados no estado de São Paulo, que apresentaram sintomas de alteração do sistema respiratório ou abortamento, e comparados os resultados com animais criados nas mesmas propriedades e que não apresentavam os referidos sintomas. Os resultados positivos observados nos dois grupos, de $23,52 \%$ e $10,34 \%$, respectivamente, para o grupo de animais com quadro respiratório e abortamento, não foi estatisticamente diferente dos animais assintomáticos (19,33\%). Considerando-se a raça dos animais, pode-se observar maior ocorrência de animais soropositivos nas raças Mangalarga, Árabe e Quarto de Milha, quando comparados aos das raças Andaluz e Puro-Sangue Inglês, bem como aos mestiços.
\end{abstract}

Palavras-chave: arterite viral; eqüinos; abortamento; respiratório.

\section{Introdução}

Arterite Viral Eqüina é uma doença contagiosa viral de eqüinos, freqüentemente confundida com a Rinopneumonite Eqüina ou Aborto Eqüino a Vírus e com a Influenza, devido à semelhança dos sintomas observados em animais infectados pelos vírus determinantes destas doenças. A Arterite Viral Eqüina (AVE) é causada por um RNA-vírus, da família Togaviridae, envelopado, esférico, com 50-70mm de diâmetro, sensível a solventes lipídicos e à maioria dos desinfetantes, e resistente a baixas temperaturas.

A AVE foi relatada pela primeira vez em 1957 por Doll et al., a partir de um surto de abortamento ocorrido em uma fazenda próxima a Bucyrus no estado de Ohio (EUA) em 1953. Nesta propriedade as éguas apresentaram, sob a forma de surto, comprometimento do trato respiratório, seguido de abortamento. Além disso, os animais infectados apresentaram também graves lesões vasculares, daí o nome de Arterite Viral Eqüina.

Entre a sua descrição em 1957 e o grande surto ocorrido em Kentucky em 1984 (McCollum e Timoney, 1984), pouca importância se dava a esta doença, pois não estava ainda bem estabelecido o seu real poder como determinante de abortamento e outras complicações e, com isso, sua capacidade de provocar grandes perdas econômicas. Porém, a partir destas constatações e do aparecimento de vários surtos na década de 80 , maior atenção tem sido dada a este "Togavírus".

Os sinais clínicos observados na AVE são bastante variáveis, porém, na maioria das vezes, os animais representam hipertemia (até $41^{\circ} \mathrm{C}$ ), que pode durar de 2 a 9 dias e que tem início entre o terceiro e décimo quarto dia após a exposição ao vírus, anorexia e apatia acompanhados de leucopenia. $O$ sinal mais evidente é o edema que acomete principalmente as mucosas das conjuntivas palpebrais, a região periorbital e fossa supra-orbital, acompanhado de corrimento ocular seroso, que pode ou não se transformar em purulento. A mucosa nasal também está afetada e pode haver corrimento nasal seroso. Além disso, edema de membros, principalmente de membros pélvicos, edema de baixo ventre com acometimento de bolsa escrotal e prepúcio nos machos e da glândula mamária nas fêmeas, dificuldade de locomoção devido às zonas de edema (Jones et al., 1957 ; Fukunaga et al., 1981).

Os quadros mais graves geralmente são observados em animais muito jovens ou então bastante debilitados onde, além dos sinais já mencionados, pode ocorrer tosse, rinopneumonite, que pode evoluir até pneumonia, linfoadenopatia da região da cabeça, enterite com diarréia, e em neonatos infectados que morreram, observou-se pneumonia intersticial bastante intensa com evolução superaguda (Golnik et al., 1981).

\footnotetext{
* Professor Doutor do Departamento de Clínica Médica da Faculdade de Medicina Veterinária e Zootecnia da Universidade de São Paulo.

** Pós-graduanda do Curso de Pós-Graduação em Clínica Veterinária do Departamento de Clínica Médica da Faculdade de Medicina Veterinária e Zootecnia da Universidade de São Paulo.
} 
As éguas infectadas podem apresentar abortamento entre o terceiro e o décimo mês de gestação, acompanhado ou não de outros sinais clínicos (Doll et al., 1957). Em estudos realizados quando da ocorrência de infecção natural em eqüinos por este vírus, observou-se que entre 10 e $60 \%$ das fêmeas abortaram (Timoney e McCollum, 1990), enquanto em estudo realizado com infecção experimental $71 \%$ das fêmeas gestantes apresentaram abortamento (Cole et al.,1986). Este mesmo tipo de diferença de comportamento é observado em relação à mortalidade, pois quando de infecção natural pelo vírus da AVE, é baixa a mortalidade, enquanto $60 \%$ dos animais experimentalmente infectados morreram devido a complicações respiratórias.

Estudos sorológicos demonstram que este vírus está presente não só na América do Norte (Lang e Mitchell, 1984 ; McCue et al., 1991), como na América do Sul (Argentina) (Nosetto et al., 1984), Europa, África (Cecarelli et al., 1972; Moraillon e Moraillon, 1978; Herbst e Schliesser, 1987), Ásia (Akashi et al., 1975), Austrália (Huntigton et al., 1990) e Nova Zelândia (Timoney e McCollum, 1990) (McCollum e Bryans, 1972), tanto na forma de surtos como em ocorrência esporádica, e também como infecção inaparente. Estas diferenças estão na dependência da quantidade de vírus a que o animal está submetido, a sua idade, a sua higidez e, em outras viroses, também a amostra ou "cepa" do vírus, porém, no caso da Arterite Viral Eqüina, só se conhece até o momento uma amostra chamada Bucyrus.

Considerando a falta de informações específicas a respeito desta virose em nosso meio, e levando-se em conta a ocorrência de sintomas clínicos semelhantes aos causados por este agente, que freqüentemente são observados em nossas criações, este trabalho tem como objetivo a determinação de anticorpos contra este vírus em propriedades, no estado de São Paulo, onde são observados abortamentos e quadros respiratórios.

\section{Material e métodos}

Foram utilizados 259 amostras de soro sangüíneo de eqüinos das raças: Andaluz (12 amostras), Árabe (25), Mangalarga (94), Puro-Sangue Inglês (47), e Quarto de Milha (36) bem como de animais Mestiços (45) criados em 15 haras ou faźendas de criação no estado de São Paulo, nos seguintes municípios: Caçapava (1 propriedade), Campinas (2), Guaratinguetá, Ibiúna (2), Mogi Mirim, Piedade, São José dos Campos (2), São Paulo (2) e Sorocaba (3). Estas amostras foram divididas em três grupos, a saber:

Grupo 1: composto por 58 amostras de soro de éguas com histórico de abortamento entre $03^{\circ}$ e $\circ 11^{2}$ mês de gestação, ocorrido entre um e doze meses antes da coIheita do material.
Grupo 2: composto por 51 amostras de soro de eqüinos que apresentaram sintomas de alteração do sistema respiratório entre 30 e 60 antes da colheita do material.

Grupo 3: Com 150 amostras de soro de eqüinos que não tinham histórico de abortamento ou de sintomas de alteração do sistema respiratório há pelo menos 1 ano, e que eram criados nos mesmos locais e condições que os animais que compõem os grupos 1 e 2 . Este grupo serviu de controle para que se pudesse avaliar a quantidade de animais soropositivos e assintomáticos nas propriedades utilizadas para colheita de amostras.

As provas de soroneutralização foram realizadas utilizando-se da macrotécnica descrita por Senne et al. (1985), utilizando-se para produção de antígeno, amostra padrão do vírus da arterite viral dos eqüinos gentilmente cedida pelo Dr. Peter J. Timoney, da Universidade de Kentucky.

\section{Resultados}

Tabela 1: Resultados da prova de soroneutralização para anticorpos antivírus da arterite viral eqüina, em animais com e sem sintomas criados no estado de São Paulo,1998

\begin{tabular}{lccc}
\hline \multirow{2}{*}{ Grupo } & \multicolumn{3}{c}{ Resultado } \\
\cline { 2 - 4 } & Positivo & Negativo & Total \\
\hline Com abortamento & 06 & 52 & 58 \\
Sintomas respiratórios & $(10,34 \%)$ & $(89,66 \%)$ & \\
& 12 & 39 & 51 \\
Sem sintomas & $(23,52 \%)$ & $(76,48 \%)$ & \\
& 29 & 121 & 150 \\
& $(19,33 \%)$ & $(80,67 \%)$ & \\
\hline Total & 47 & 212 & 259 \\
\hline
\end{tabular}

Tabela 2: Resultados da prova de soroneutralização para anticorpos antivírus da arterite viral eqüina, em animais com histórico de abortamento, criados no estado de São Paulo,1998

\begin{tabular}{lccc}
\hline & \multicolumn{3}{c}{ Resultado } \\
\cline { 2 - 4 } Raça & Positivo & Negativo & Total \\
\hline Andaluz & - & 2 & 2 \\
Árabe & 1 & 4 & 5 \\
Mangalarga & 1 & 23 & 24 \\
Mestiços & - & 9 & 9 \\
Puro-sangue inglês & - & 6 & 6 \\
Quarto de milha & 4 & 8 & 12 \\
\hline Total & 6 & 52 & 58 \\
\hline
\end{tabular}


Tabela 3: Resultados da prova de soroneutralização para anticorpos antivírus da arterite viral eqüina, em animais com sintomas respiratórios, criados no estado de São Paulo,1998

\begin{tabular}{lccc}
\hline & \multicolumn{3}{c}{ Resultado } \\
\cline { 2 - 4 } Raça & Positivo & Negativo & Total \\
\hline Andaluz & - & 2 & 2 \\
Árabe & 2 & 4 & 6 \\
Mangalarga & 7 & 17 & 24 \\
Mestiços & - & 6 & 6 \\
Puro-sangue inglês & 3 & 8 & 11 \\
Quarto de milha & - & 2 & 2 \\
\hline Total & 12 & 39 & 51 \\
\hline
\end{tabular}

Tabela 4: Resultados da prova de soroneutralização para anticorpos antivírus da arterite viral eqüina, em animais sem sintomas da doença, mantidos em propriedades onde existem animais com sintomas. São Paulo,1998

\begin{tabular}{lccc}
\hline & \multicolumn{3}{c}{ Resultado } \\
\cline { 2 - 4 } Raça & Positivo & Negativo & Total \\
\hline Andaluz & 1 & 7 & 8 \\
Árabe & 6 & 8 & 14 \\
Mangalarga & 11 & 35 & 46 \\
Mestiços & 3 & 27 & 30 \\
Puro-sangue inglês & 5 & 25 & 30 \\
Quarto de milha & 3 & 19 & 22 \\
\hline Total & 29 & 121 & 150 \\
\hline
\end{tabular}

\section{Discussão}

A prevalência de soropositividade para anticorpos contra o vírus da arterite viral dos eqüinos nos animais sem sintomas clínicos da doença $(19,33 \%)$, são equivalentes àquelas já descritas no estado de São Paulo por Souza (1996),e na Itália (Cavirani et al., 1990) e na França e em outros países europeus e africanos (Moraillon, Moraillon,1978), e indica que esta infecção está disseminada em nosso meio.

Quando analisamos os resultados obtidos levando em conta a raça dos animais, podemos observar que existe um maior índice de animais soropositivos entre aqueles da raça Mangalarga, seguido do Àrabe, do Puro-Sangue Inglês e do Quarto de Milha, o que indica que o fator racial interfere na ocorrência deste fato, o que vem a corroborar as observações apresentadas por Lang e Mitchell(1984), Cavirani et al. (1990), Elazhary et al. (1990), Huntington et al. (1990), McCue et al. (1991), Ghram et al. (1994) e também de Souza (1996).

Com relação aos resultados obtidos para os soros dos animais com suspeita clínica da doença, quer com abortamento, quer com alterações do sistema respiratório, eles não são estatisticamente diferentes dos animais sem sintomas compatíveis com a doença, porém indicam que a Arterite Viral dos Eqüinos está ocorrendo no estado de São Paulo, nas suas formas mais comuns de manifestação clínica da doença descritas por vários autores como Doll et al., 1957; Timoney, McCollum, 1990, quais sejam o abortamento e as alterações respiratórias, bem como na forma de infecção inaparente.

\section{Abstract \\ Anti-viral arteritis virus antibodies were detected from the serum of horses raised in São Paulo State, which presented abortion or symptoms of respiratory alterations. The positive results were of $10,34 \%$ and $23,52 \%$ for the group of animals with abortion and respiratory syumptoms, respectively, which was not statisticaly different from assymptomatic animals $(19,33 \%)$. Considering the horse breed, more positive cases were observed in Mangalarga, Arabian and Quarter Horse when compared to Andaluz, English throughbreed and mixed breed.}

Keywords: Equine; viral arteritis; abortion; respiratory.

\section{Referências bibliográficas}

AKASHI, H., KONISHI, S., OGATA, M. Studies on equine viral arterites II . A serological survey of equine viral in horses imported in 1973/74. Japanese Journal of Veterinary Science, v. 38, n. 1, p. 71-73,1975.

CAVIRANI, S., ALLEGRI, G., FLAMMINI, C. F. Anticorpi verso i vírus della rinopolmonite (EHV-I), dell'arterite virale e dell'influenza nel siero di cavalli sportivi e da competizione. Obiettivi e Documenti Veterinari, v. 11, n. 4, p. 43-46, 1990.

CECCARElli, A., AGRIMI, P., PIRAGINO, S. Ricerche sierologiche sulla arterite virale equina in Italia. Zooprofilarsi, v. 27, n. $7 / 8$, p. $245-256,1972$.
COLE, J.R., HALL, R.F., GOSSER, R.S. et al. Transmissibility and abortigenic effect of equine viral arteritis in mares. $J$. Am. Vet. Med. Assoc., n. 189, p. 769, 1986.

DOLL, E.R., BRYANS, J.T., McCOLLUM, W.H., CROWE, M. Isolation of a filterable agent causing arteritis of horses and abortion by mares. Its differentiation from the equine abortion(influenza) vírus. Cornell Vet. v. 47, n. 3, 1957.

ELAZHARY, Y., GOULARD, C., VRINS, A., FASSI-FHM, 0. Artérite virale équine au Quebec: étude sérologique. Le Médecin Vétérinaire Du Québec, v. 20, n. 1, p. 25-27, 1990.

FUKUNAGA, Y.; IMAGAWA, H.; TABUCHI, E. et al: Clinical and virological findings on experimental equine viral arteritis in horses. Bull Equine Res. Inst. v. 18, n. 110, 1981. 
GHRAM, A., CHABCHOUB, A., TURKI, I., BOUSSETTA, M., IBN AMOR, H., GHORBEL, A. La rhinopneumonie et l'artérite à virus du cheval: etude séro-épidérniologique dans le nordest de la Tunisie. Archives de L'Institut Pasteur de Tunis, v. 71, n. 1, p. 5-12, 1994.

GOLNIK,W., MICHALASKA, Z., MICHALAK, T. Natural equine viral arteritis in foals. Schweiz Arch Tierheilkd, v. 123, p. 523, 1981.

HERBST, W.; SCHIESSER, T. Serologische verlaufsuntersuchungen bei der virusarteritis des pferdes in einem gestüt. Journal of Veterinary Medicine, Series B-Infectious Diseases, Immunology, Food, Hygiene, Veterinary Public Healt, v. 34, n. 4, p. 283-287, 1987.

HUNTINGTON, P. J., FORMAN, A. J., ELLIS, P. M. The occurrence of equine arteritis virus in Australia. Australian Veterinary Journal, v. 67, n. 12, p. 432-435, 1990.

JONES, T.C., DOLL, E.R., BRYANS, J.T. The lesions of equine viral arteritis. Cornell Vet., n. 47, p. 52, 1957.

LANG, G.; MITCHELL, W. R. A serosurvey by Elisa for antibodies to equine arteritis virus in Ontario racehorses. Equine Veterinary Science, v. 4, n. 4, p. 153-157, 1984.

MCCOLLUM, W.H., BRYANS, J.T. Serological identification of infection by equine arteritis virus in horse of several countries. In Proceedings of the Third International Conference of Equine Infectious Diseases, Paris, 1972, p. 256.

MCCOLLUM, W.H., TIMONEY,P.J. The pathogenic qualities of the 1984 strain of equine arteritis virus. In Proceedings of the grayson Foundation International Conference of Thoroughbred Breeders Organizations, Drumoland Castle, Ireland, 1984, p. 34.
MCCUE, P. M., HETALA, S. K., SPENSLEY, M. S., STELLIAN, M., YI, J., HUGHES, J. P. Prevalence of equine viral arteriais in California horses. California Veterinarian, v. 45, n. 2, p. $24-$ 26, 1991.

McCUE,P.M., HIETALA, S.K., SPENSELY, M.S. et al. Prevalence of equine viral arteritis in California horses. California Veterinarian, n. 45, p. 24, 1991.

MORAILLON, A., MORAILLON, R. Results of an epidenúologicai investigation on viral arteriais in France and some other European and Afiican countiies. Annales de Recherches Vétérinaires, v. 9, n. 1, p. 43-54, 1978.

NOSETTO, E. O., ETCHEVERRIGARAY, M. E., OLIVA, G. A., GONZÁLEZ, E. T., SAMUS, S. A. [Arteritis viral equina: detección de anticuerpos en equinos de la República Argentina]. Zentralblatt rur Veterinarmedizin, B, v. 3 I, n. 7, p. 526-529, 1984.

SENNE, D. A., PEARSON, J.E., CARBREY, E. A. Equine viral arterites: a standard procedure for the virus neutralization test and comparison of results of a proficiency test performed at five laboratories. In: Proccedings of the United States Animal Health Association, v. 89, p. 29-34,1985.

SOUZA, M.C.C. Prevalência da infecção pelo vírus da arterite viral dos eqüinos em cavalos criados no Estado de São Paulo. 1996. 81 p. Dissertação (Mestrado). Faculdade de Medicina Veterinária e Zootecnia da Universidade de São Paulo.

TIMONEY, P. J., McCOLLUM, W.H. Equine viral arteritis: Current clinical and economic significance. Proc American Association of Equine Practitioner, n. 36, p. 403, 1990. 